\title{
Yaşam Doyumunun Yordayıcısı Olarak Boş Zaman Tatmini
}

\author{
Predictive Role Of Leisure Time Satisfaction On Life Satisfaction
}

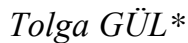

\section{$\ddot{O} Z$}

Bu araştırmanın amacı bir sayfiye yeri olan Alanya'da üniversite okuyan ögrencilerin, boş zaman tatminlerinin yaşam doyumuna etkisinin belirlenmesi ve bunlar arasındaki ilişkinin incelenmesidir. Araştırma 2018-2019 ĕgitim ögretim yllı içerisinde Alanya Alaaddin Keykubat üniversitesinde okuyan toplam 12,122 öğrenciden evrenini temsil etmesi düşünülen toplam 335 öğrenci araştırmaya katılmıştır. Araştırma kapsamında öğrencilerin boş zaman tatminlerinin yaşam doyumlarına olan etkisi ile birbirleriyle olan ilişkisine yönelik veri temin edilmiştir. Verilerin elde edilmesinde Boş Zaman Tatmin ölçeği ile yaşam doyum ölçeği kullanılmıştır. Ayrıca ankette yer alan demografik ve kişisel sorulardan elde edilen verilere göre boş zaman tatmini ve yaşam doyumuna iliş̧in öğrenci görüşleri arasındaki farklar da incelenmiştir. Araştırmada regresyon ve korelasyon analizi ile Farklılıkların belirlenmesi için değişken sayısına göre Mann Whitney $U$ ve Kruskal Wallis testleri de kullanılmıştır. Yapılan regresyon analizine göre boş zaman tatmininin, yaşam doyumuna anlamlı bir etkisi olduğu, korelasyon analizine göre boş zaman doyumu ile yaşam doyumu arasında pozitif yönlü anlamlı bir ilişki olduğu belirlenmiştir. Boş zaman tatmini ve yaşam doyumu elde etmede cinsiyet, yaş, eğitim düzeyi, uyku süresi bakımından gruplar arasında anlamlı bir farklılı̆̆a rastlanmamıştır.

\section{ANAHTAR KELIMELER}

Boş zaman, Boş Zaman Tatmini, Yaşam Doyumu, Rekreasyon

\begin{abstract}
This study aims to determine the effect of leisure satisfaction on life satisfaction of university students in Alanya, where is coastal area, and to investigate the relationship between them. The research was carried out in a total of 335 inquiries which are thought to represent the universe of 12,122 students studying at Alanya Alaaddin Keykubat University in 20182019 academic year. Within the scope of the research, data on the effect of leisure time satisfaction on life satisfaction and the relationship between each other were provided. Leisure satisfaction and life satisfaction scale were used to obtain the data. Besides, the differences between the opinions of students about leisure satisfaction and life satisfaction were examined according to the data collected from the demographic and personal questions in the survey. In the study, Man Witney $U$ and Kruskal Wallis tests were used to determining the differences by regression and correlation analysis. According to the regression analysis, it was found that the satisfaction of leisure time had a significant effect on life satisfaction, and according to the correlation analysis, it was determined that there was a positive relationship between leisure time satisfaction and life satisfaction. No significant differences were found between the groups in terms of gender, age, education level, and sleep duration in obtaining leisure satisfaction and life satisfaction.
\end{abstract}

\section{KEYWORDS}

Leisure time, Leisure time Satisfaction, Life Satisfaction, Recreation

\begin{tabular}{|c|c|c|}
\hline & $\begin{array}{l}\text { Makale Geliş Tarihi / Submission Date } \\
01.06 .2019\end{array}$ & $\begin{array}{c}\text { Makale Kabul Tarihi / Date of Acceptance } \\
24.11 .2019\end{array}$ \\
\hline Atıf & $\begin{array}{l}\text { Gül, T. (2019). Yaşam Doyumunun Yordayıc1s1 } \\
\text { Meslek Yüksekokulu Dergisi, } 22 \text { (2), 914-930. }\end{array}$ & Olarak Boş Zaman Tatmini. Selçuk Üniversitesi Sosyal Bilimler \\
\hline
\end{tabular}

\footnotetext{
* Dr. Öğr. Üyesi, Alanya Alaaddin Keykubat Üniversitesi, tolga.gul@alanya.edu.tr, ORCID:0000-0002-5218-082X
} 


\section{GíRiș}

Varoluşun bir sonucu olarak günde 24 saatlik “zaman”, tüm insanlara eşit olarak sunulmuştur. Bu yönüyle "Zaman" paha biçilmez, iktisadi anlamda değerli olan kıt bir kaynaktır. Yani; depolanamaz, satılamaz, hızlandırılamaz ve yavaşlatılamaz (Gajewska ve Piskrzyńska, 2017: 58). Ancak insanlığa sunulan bu 24 saatlik zamanın tamamı, insanlar tarafından aynı oranda faydalı bir şekilde kullanılmamaktadır. Bu durumdan ötürü birçok insan, sahip olduğu zamanın ne kadar değerli olduğunun farkında olmasına rağmen, zamanı doğru yönetememektedir. Sonuç olarak normal birey, sabahın erken saatlerinden akşamın karanlığına kadar zorunlu olarak hayatını işe, ders çalışmaya ve benzeri faaliyetlere tahsis eder (Hamid, Ahmad ve Wang, 2016: 729).

Yirmi birinci yüzyıl dünyasında çalışma ve serbest zamandan arta kalan sürede, rekreatif etkinlikler gerçekleştirmek insanlara motivasyon, mutluluk ve yaşama doyuma ulaşmalarına yardımcı olmaktadır. Yani bireylerin boş zamanlarında gerçekleştirdikleri faaliyetler yaşamda ayrılmaz bir parçasıdır. Yaşamdaki boş zamanları iyi planlamak ve faaliyetlerle doldurmak, bireyin iyi bir yaşam sürmesine yardımcı olabilir. Bu bağlamda bilimsel çalışma yapan; Wang vd. (2008), Gökçe (2008), Lapa, (2013), Argan vd. (2013), Kılıç vd. (2016), Muzindutsi, ve Masango (2015), Yaşartürk vd. (2017), Yürcü (2017), Freire ve Teixeira (2018) ve Tepeköylü Öztürk (2019) araştırmacılar, ulaştıkları sonuçlara göre boş zamandan elde edilen tatminin, bireyleri stres, kaygı, monotonluk ve mutsuzluktan kaynaklanan olumsuzluklardan uzaklaştırarak yaşam doyumu elde ettiği sonucuna ulaşmışlardır. Sonuç olarak hayattan yaşam doyumu elde etme, bireyin fizyolojik ve psikolojik sağllğıyla doğrudan ilişki içerisinde olduğu söylenebilir. Yani özet olarak bireylerin eğitimi, beslenme biçimi, yaptığı faaliyet, çalışma ortamı, psikolojik durumu, estetik algısı ve benzeri tüm etkenler ruhsal ve bedensel hayatlarını etkilemektedir (Yaşartürk vd., 2018: 134).

Gençler için boş zaman faaliyetleri, özellikle kişisel ve toplum gelişimi ile ilgili olduğu kadar, kamu ve özel sektör alanında ileride ihtiyaç duyulacak yetişmiş işgücünün sağlanması bakımından önemlidir. Bu yönüyle boş zaman faaliyetleri en temelde sağlık, riskli davranışını azaltma, eğitim, istihdam ve siyasi katılım gibi sağladığ faydalarla devletlerin gençlik politikasının temelini oluşturmaktadır. Aslında bu durum, insan kaynağını geliştirmenin temelini oluşturarak, sivil ve ekonomik kalkınma hedeflerin sürdürülebilirliğini sağlamaktadır. Bu, insanların dünya üzerinde çalışma hayatına hazırlığın son dönemi olan üniversite dönemi bireylerin kişiliklerinin geliştirmedeki son istasyondur. Bu yönüyle üniversiteler öğrencileri için, sosyal ve akademik yaşamın dengelenmesi bakımından karmaşık bir yapıya sahiptir. Üniversite kampüsleri eğitimin yanında öğrencilerin eş zamanlı olarak sosyal yaşama katılımı da sağlayarak, öğrenciler için rekreatif faaliyetlere katılmayı da sağlamalıdır (Muzindutsi, ve Masango, 2015: 34).

Sonuç olarak sayfiye bölgesinde üniversite okuyan öğrenciler, boş zaman tatminlerinin yaşam doyumlarına olan etkisinin incelenmesi ve aralarında olan ilişkinin belirlenmesi bu çalışmanın amacını oluşturmaktadır. Bu kapsamda, tüm dünyada bir turizm destinasyonu olarak bilinen Alanya'nın bireylerin boş zamanlarını değerlendirilmek üzere geldiği bir eğlence ve dinlence yani, bir rekreatif çekim merkezi olması, bu destinasyonda okuyan öğrenciler için boş zamanları tatmin etme düzeyi ile yaşam doyumlarına olan katkısını belirlemek bu çalışmayı önemli kılmaktadır. Araştırmanın Alanya sınırlarında bulunan bir üniversitede yapılması ayrıca önemlidir. Araştırma Alanya'da bulunan üniversite kampüsündeki öğrencilerin boş zaman tatminlerinin yaşam doyumuna olan etkisini belirlenmesi ve demografik değişken, kişisel ve rekreatif davranış farklılıklarına göre boş zaman tatmini ve yaşam doyumları arasındaki ilişkinin belirlenmesi bakımından da önemlidir.

\section{KAVRAMSAL ÇERÇEVE}

Boş zaman, insanın varoluşu için gerekli olanların ötesinde biyolojik olarak yapılması gereken şeyleri yani; yeme-içme, uyumak, kişisel bakım, boşaltım, temizlenmek, yok etmek, ilaçlamak ve benzeri faaliyetlerin ötesinde hedonist arzulara yönelik yapılan faaliyetler için harcanan zamandır. Boş zaman isteğe bağlı zaman, kendi kararımıza veya tercihimize göre kullanılan, süreç olarak zorlama duyguların en düşük düzeyde olduğu zaman olarak tanımlanabilir (Brightbill, 1960: 4). Avusturalya Sağlı Bakanlığının (1980) "Recreation Working Paper" da yayımlanan Physical Education and Recreation/Royal Australian Institute of Parks and Recreation adlı makalede "Boş Zaman" (Leisure Time), teorik olarak zorunlu olmayan zaman ve istekli iyimserlik ile nitelendirilen bir zihinsel durum olarak açıklanmaktadır. Boş zaman bu yönüyle bakıldığında içerisinde bir aktif olarak bir faaliyette bulunmak zorunluluk değildir. Temel nosyon, bireyin içinde bulunduğu ortamındaki öğelerle barışçıl ve üretken bir arada varoluşu teşvik eden bir tutum içerisinde bulunmasıdır (Veal, 1992: 45). Alanyazında boş zaman üzerinde ilk tanımlama yapan yazarlardan; Torshtain Veblen (1899) boş zamanı, toplum içerisinde sınıf ayrımını sağlayan bir araç ve üst sınıfa dâhil olmanın sembolü olduğunu belirtmektedir. De Grazia (1962) boş zamanlarını ütopik bir varoluş hali olarak tanımlamaktadır. Neulinger (1974) boş zamanı, algılanan özgürlük, içsel motivasyon, hedef odaklılık ve iş ilişkisi olarak açılamaktadır. 
Son olarak Kaplan (1975) boş zaman için "kişisel gelişim ve sosyal hizmet için bir araç olarak hizmet eden özerk bir çaba" olarak tanımlama yapmıştır (Trujillo, 2007: 30). Boş zaman, hükümetler ve özel teşebbüs tarafından üretimin sürdürülebilirliği için yasal olarak insanlara hukuki olarak sunulan günübirlik, hafta sonu ve uzun tatil gibi dış etkenlerin kaçınılmaz bir sonucu değildir. Zihinsel ve ruhsal bir tutumum bir parçasıdır (Pieper, 1965: 43). Torkildsen (1993: 26) Boş zaman kavramını mutlu olmak için Düşünme Zamanı, Felsefe, Derin Düşünme ve Kendini Geliştirme Zamanı olarak tanımlamaktadır.

İçinde bulunduğumuz yüzyılda sosyal bilimler alanında araştırma yapanlar, yaşam memnuniyetini kontrol eden faktörleri anlamada bir atılım yaratarak yayımlanan eser sayısında bir artış sağlamışlardır. Buna bağlı olarak yaşam memnuniyetini ölçmenin güvenilir yolları geliştirilmiştir. Sonuç olarak bu alanda önemli bir bilgi birikimi elde edilmiştir (Veenhoven, 2015: 209). Yaşam doyumu için alanyazında birçok tanımlama var olmasına rağmen, yaşam doyumu tanımını teorik olarak tek bir tanım etrafında toplamak mümkün değildir. Yaşam doyumu kavramı üzerine çalışan Neugarten yaşam doyumunu, başarılı yaşlanmanın operasyonel hali olarak tanımlarken, Sumner ise, sahip olunan yaşam koşullarının, standartlarınıza veya beklentilerinize uygun bir şekilde ölçülmesi ve buradan çıkan yargının olumlu bir değerlendirmesi olarak tanımlamaktadır (Prasoon ve Chaturvedi, 2016: 26). Hamilton (1995), yaşam doyumunu, kişinin kendi yaşam tarzı ile ilgili elde ettiği memnuniyet derecesi olarak tanımlarken, Cribb, (2000) yaşam doyumunu, kişinin gerçek başarıya olan özleminin karşılaştırılmasından elde edilen genel varoluş koşullarının bir değerlendirmesi olarak açıklamaktadır. (Prasoon ve Chaturvedi, 2016: 27, Madiha ve Akhouri, 2018: 21). Lippman (2012) ve arkadaşları yaşam doyumunu, insanın kendi hayatından memnun olma algısı ve hayatının doğru yolda olduğu inancı olarak tanımlar. Sonuç olarak bireyin yaşadığı hayattan elde ettiği doyum, geçmişteki tecrübelerinden elde ettiği doyum, gelecekten hayallerinden beklediği doyum, çevresini önemsemesi ve yaşamını değiştirme isteği bireyin yaşam doyumu olarak tanımlanmaktadır. Yaşam doyumunun elde edildiği genel alanlar; sosyal çevre ve çalışma çevresi, boş zaman sahipliği ve süresi, sağlık, para, psikolojik iyi oluş ve eğitim çevresi olabilmektedir (Hilooğlu ve Cenkseven-Önder, 2010: 1161).

\section{YÖNTEM}

\subsection{Araştırmanın modeli}

$\mathrm{Bu}$ araştırmanın amacı sayfiye bölgesinde üniversite okuyan öğrencilerin, boş zaman tatminlerinin yaşam doyumuna olan etkinin incelenmesi ve aralarında olan ilişkinin belirlenmesidir. $\mathrm{Bu}$ araştırmanın önemi, insanların boş zamanlarını değerlendirmek üzere gelinen bir eğlence, dinlence, sayfiye kısaca bir rekreatif çekim merkezi olan Alanya'da eğitim alan öğrenciler için boş zamanları tatmin etme düzeyi ile yaşam doyumlarına olan katkısını belirlemektir. Araştırma amacından yola çıkılarak hazırlanan araştırma modeli Şekil 1 de verilmiştir. Bu kapsamda araştırma için toplam 7 adet araştırma sorusu geliştirilmiştir.

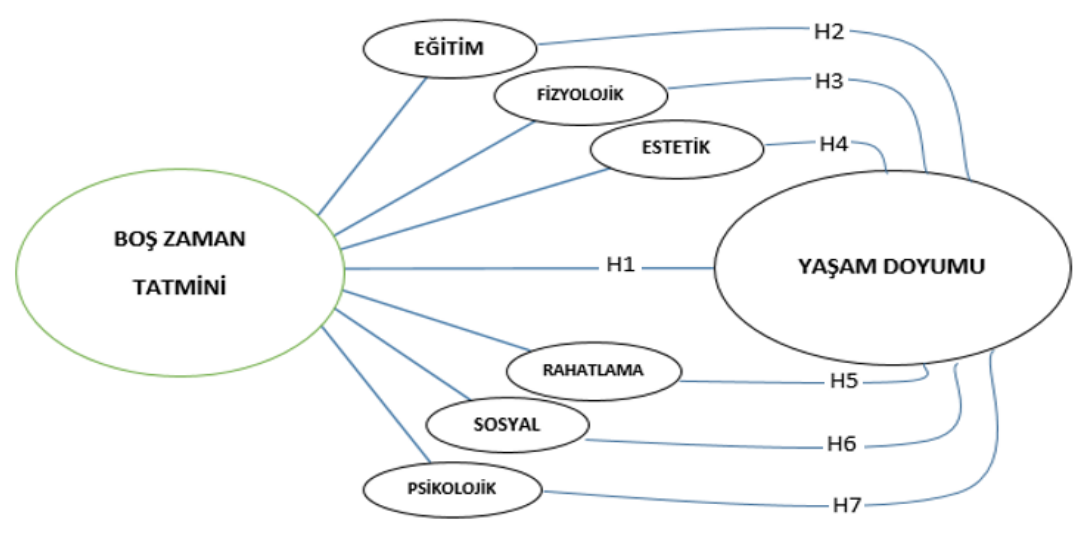

Şekil 1: Araştırmanın Modeli

Appleton ve Song (2008) yaşam doyumunun meydana getiren altı farklı bileşen olduğunu ileri sürerek; bu bileşenlerin; "gelir düzeyi, eğitim düzeyi, psikolojik durum, refah koşulları, sosyal ve siyasal çevresi" olarak belirtmiştir (Dağlı ve Baysal, 2016: 1251). Bu kapsamda araştırmanın modeli (Şeki1) kapsamında, Boş Zaman Tatmin ölçeğinin 6 temel alt boyutu, bireyleri yaşam doyumuna ulaştıran altı birleşen ile uyum içerisindedir. Bu kapsamda araştırma hipotezlerimiz aşağıdaki gibi geliştirilmiştir;

H1: Boş zaman tamiminin öğrencilerin yaşam doyumları üzerine bir etkisi vardır. 
H2: Boş zaman tatmininin "Eğitim" boyutunun öğrencilerin yaşam doyumları üzerine bir etkisi vardır.

H3: Boş zaman tatmininin "Fizyoloji” boyutunun öğrencilerin yaşam doyumları üzerine bir etkisi vardır.

H4: Boş zaman tatmininin "Estetik" boyutunun öğrencilerin yaşam doyumları üzerine bir etkisi vardır.

H5: Boş zaman tatmininin "Rahatlama" boyutunun, öğrencilerin yaşam doyumları üzerine bir etkisi vardır.

H6: Boş zaman tatmininin "Sosyal" boyutunun, öğrencilerin yaşam doyumları üzerine bir etkisi vardır.

H7: Boş zaman tatmininin "Psikolojik" boyutunun, öğrencilerin yaşam doyumları üzerine bir etkisi vardır.

\subsection{Araştırma grubu}

$\mathrm{Bu}$ araştırma Alanya Alaaddin Keykubat üniversitesinde 2018-2019 eğitim öğretim y1lı içerisinde okuyan toplam 335 öğrenci üzerine yapılmıştır. Anket araştırmaya katılmayı kabul eden öğrencilere ölçek soruları yöneltilmiştir. Araştırma örnekleminin belirlenmesinde "rastgele seçme yöntemi" uygulanmıştır. Ders zamanlarının farklı olması, tüm öğrencileri tek bir noktada toplama problemi, mekân sınırlılıkları ve zaman kısıtı nedeniyle evrenin tamamına ulaşmak imkânsız olmuştur. Bu durumda evrenin içinde yer alan, özellikleri ve verdikleri cevaplar açısından evreni temsil edecek bir grup öğrenciden bilgi toplanmıştır. Örneklem grubunun belirlenmesinde herhangi bir sistematik kişi seçimi yapılmayan "Basit Rastgele" örnekleme yöntemi kullanılmıştır. Bu yöntemin uygulanması kampüs içerisinde belirli bir yerde durup, karşılaşılan herhangi bir öğrenci grubuyla görüşülerek veri toplanma yöntemidir (Özdamar, 2001, Arıkan, 2004, Kılıç, 2013). Bu kapsamda Alanya Alaaddin Keykubat üniversitesi Kestel kampüsü içerisinde 2018-2019 eğitim öğretim yılı Bahar dönemi içerisinde okuyan 12122 öğrenci evrenini temsil etmesi bakımından azami 367 (Yazıcıŏlu ve Erdoğan, 2004, 50) olması gerekmektedir. Bunun dışında araştırmalarda evren hacmi büyüklüğü ( $>10.000$ veya $\mathrm{N}<10.000$ ), değişkenlerin türü (nitel veya nicel) ve güven düzeyinin (1- $\alpha$ ) göz önünde bulundurulup bulundurulmayacağı gibi belirleyiciler dikkate alınarak evreni temsil edecek örneklem sayısının hesaplanması için Özdamar, $(2001 ; 57)$ eserinde aşağıdaki formülü vermiştir. Bu kapsamda araştırmanın evreni aşağıdaki formüle göre belirlenmiştir;

2500.N. $(1,96)^{2}$

2500.12122. $(1,96)^{2}$

Örneklem büyüklüğü=

$$
[25(\mathrm{~N}-1)]+\left[2500 *(1,96)^{2}\right]
$$

$$
\text { Örneklem büyüklüğü }=\frac{2500.12122 .(1,}{[25(12122-1)]+\left[2500 *(1,96)^{2}\right]}
$$

Örneklem büyüklüğ̈̈= $372,38 \Rightarrow 373$ öğrenci olarak belirlenmiştir. Yukarıdaki formülden yola çıkılarak yapılan hesaplama neticesinde, üniversite kampüsü içerisinde 750 anket dağıtılmış ancak bunlardan sadece 335 adedi araştırma kapsamında kullanılmaya uygun bulunmuştur.

\subsection{Veri toplama araçları}

Boş zaman tatminin yaşam doyumu arasındaki ilişkiyi araştırdığımız bu çalışmaya veri toplamak üzere araç olarak anket yöntemi kullanılmıştır. Araştırmaya veri toplamak üzere anket içerisinde Boş Zaman Tatmin ölçeği (Leisure Satisfaction Scale) ile Yaşam Doyum ölçeği (Life Satisfaction) kullanılmıştır. Boş zamana ve yaşam doyumuna ilişkin tatmin veya tatminsizliği değerlendirecek bir ölçek bulunmamaktadır. Bu nedenle alanyazında geçerlilik ve güvenilirliği (Misra ve McKean, 2000; Siegenthaller ve O'Dell, 2000; Lloyd ve diğ., 2001; Lysyk vd., 2002; Lloyd ve Auld, 2002; Hou vd., 2007; Ngai, 2005; Trottier vd., 2002; Lu ve Hu, 2005; Pearson, 2008; Karl1, Polat, Y1lmaz ve Koçak, 2008) test edilen Beard ve Ragheb (1980) tarafından geliştirilmiş olan Boş Zaman Tatmin Ölçeği'nin 39 ifade ve toplam altı boyuttan meydana gelen ölçek kullanılmıştır. Ölçeklerden elde edilen güvenirlilik analizi sonuçlarına göre, Boş Zaman Tatmin ölçeğinden alınan verilerin güvenirlilik düzeyi; $(\alpha: 0,863)$ yaşam doyum ölçeğinden elde edilen verilerin güvenirlilik düzeyi $(\alpha: 0,813)$ olarak görülmüştür. İfadelere ilişkin öğrenci görüşlerini sayısal olarak tanımlamak üzere beşli Likert 1-5 aralığında derecelendirme sistemi kullanılmıştır. Yaşam doyumunu ölçmek üzere öğrencilerin boş zaman tatminlerinin yaşam doyumlarına olan etkisini ve aralarındaki ilişkiyi belirlemek üzere ankette Diener, Emmons, Laresen ve Griffin (1985) tarafından geliştirilen ve Dağlı ve Baysal (2016)'ın Diyarbakır şehir merkezinde görev yapan öğretmenler üzerine yaptığı "Yaşam Doyumu Ölçeğinin Türkçe'ye Uyarlanması: Geçerlilik ve Güvenlilik Çalışması adlı çalışmalarında Türkçe' ye çevirdikleri "Yaşam Doyum Ölçeğì" kullanılmıştır. 


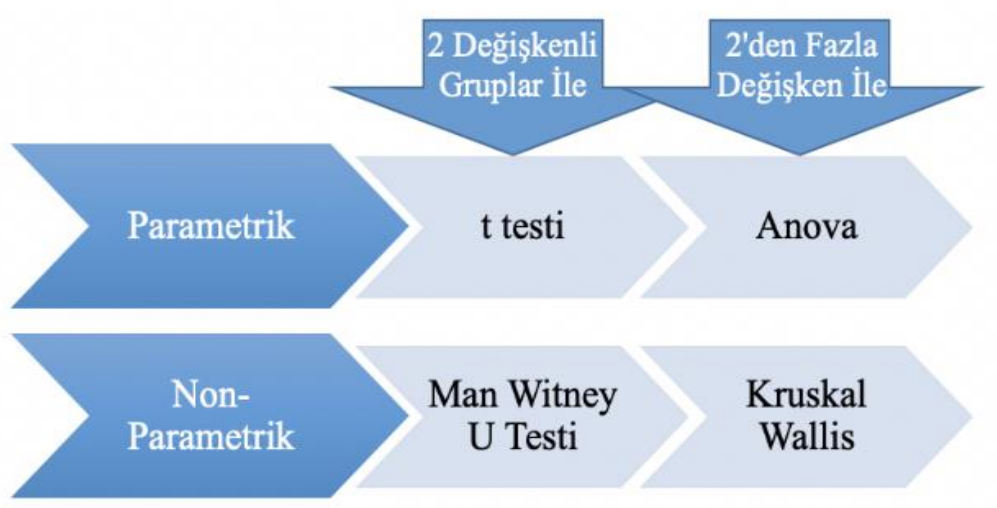

Şekil 2:Teste Karar Verme Süreci

Araştırma kapsamında demografik ve kişisel veriler ile ölçeklerden elde edilen verilerin karşıllaştırılmasında yapılacak analize karar verilirken şekil 2'den yararlanılmıştır. Şekil 2'ye göre bağımlı değişken sayısı en fazla 2 iken bağımsız değişkenlere uygulanan normallik testi sonucu parametrik ise T testi, non-parametrik ise Man Witney U Testi uygulanmıştır. Karşılaştırılan gruplarda bağımlı değişken sayısı 2'den fazla, bağımsız değişkenlere uygulanan normallik testi sonucuna göre veriler parametrik ise Anova, non-parametrik ise Kruskal Wallis uygulanmıştır.

\section{BULGULAR}

Araştırmaya katılmayı kabul eden öğrencilere ilişkin demografik ve kişisel bilgilere ilişkin tanımlayıcı verilere Tablo 1'de yer verilmiştir. Tablo 1 kapsamında araştırmaya katılmayı kabul eden öğrencilerin, \%49,3'ü erkek, \%50,7'si kadınlardan meydana gelmektedir. Katılımciların \%73,4’ü 18-22 yaş aralığında, \%23,0'ü 23-25 yaş aralığında, \%3'ü 26-30 yaş aralığında ve \%0,6'sı 31 yaş ve üzerinde olduğunu görülmüştür. Öğrencilerin hangi tip eğitim alıyorsunuz sorusuna verdikleri yanıtlara göre; \%6,3'ü önlisans ve \%93,7'si ise lisans eğitimi aldığı belirlenmiş. Öğrencilere günlük uyku sürelerinin sorulduğu soruya \%43,0'ü günlük 1-6 saat aralığında uyuduğunu, \%49,0'u 7-9 saat aralığında, \%7,8'i $10-12$ saat aralığında ve $\% 0,3$ 'ü ise 12 saat üzerinde uyuduğunu belirtmişlerdir.

Tablo 1: Öğrencilerin Demografik ve Kişisel Tercihlerine ilişkin frekans tablosu

\begin{tabular}{|c|c|c|c|}
\hline \multicolumn{2}{|l|}{ CINSIYYET } & $\mathrm{n}$ & $\%$ \\
\hline & Erkek & 165 & 49,3 \\
\hline & Kadın & 170 & 50,7 \\
\hline \multicolumn{2}{|l|}{ YAŞ } & $\mathrm{n}$ & $\%$ \\
\hline & $18-22$ & 246 & 73,4 \\
\hline & $23-25$ & 77 & 23 \\
\hline & $26-30$ & 10 & 3 \\
\hline & $31-60$ & 2 & 0,6 \\
\hline \multirow[t]{3}{*}{ EĞİTìM } & & $\mathrm{n}$ & $\%$ \\
\hline & Ön Lisans & 21 & 6,3 \\
\hline & Lisans & 314 & 93,7 \\
\hline
\end{tabular}

\begin{tabular}{|l|l|l|l|}
\hline \multicolumn{2}{|l|}{ UYKU SÜRESİ } & $\mathrm{n}$ & $\%$ \\
\hline \multirow{5}{*}{} & $1 . \mathrm{Haz}$ & 144 & 43 \\
\cline { 2 - 4 } & 7.Eyl & 164 & 49 \\
\cline { 2 - 4 } & 9.Kas & 26 & 7,8 \\
\cline { 2 - 4 } & 12 saat üzeri & 1 & 0,3 \\
\hline \multirow{5}{*}{ BOŞ ZAMAN MEKÂN TERCIHII } & $\mathrm{n}$ & $\%$ \\
\hline \multirow{5}{*}{} & Açık alan (KIR) & 124 & 37 \\
\cline { 2 - 4 } & Açık alan(KENT) & 119 & 35,5 \\
\cline { 2 - 4 } & Kapalı Alan & 76 & 22,7 \\
\cline { 2 - 4 } & Hepsi & 16 & 4,8 \\
\hline $\begin{array}{l}\text { BOŞ ZAMAN FAALIYET } \\
\text { TERCİHİ }\end{array}$ & $\mathrm{n}$ & $\%$ \\
\hline \multirow{5}{*}{} & Aktif & 186 & 55,5 \\
\cline { 2 - 4 } & Pasif & 133 & 39,7 \\
\cline { 2 - 4 } & Hepsi & 16 & 4,8 \\
\hline
\end{tabular}

Öğrenciler boş zamanlarında mekân tercihinin sorulduğu soruda, \%37,0'1 Açık Alan Kır mekânını, \%35,5'i Açık Alan Kent mekânını, \%22,7'si sadece Kapalı Alan mekânını ve geri kalan 4,8'i ise "Hepsini” kullandığını belirtmiştir. Öğrencilere boş zamanların değerlendirmek üzere faaliyete katılım biçimi sorulmuş, \%55,5'i boş zaman faaliyetine katılım tercihi Aktif katılımlı olduğunu, \%39,7'si ise Pasif katılımlı olduğunu belirtmiştir.

Araştırmanın temel hipotezlerinin test edildiği regresyon analizlerine ilişkin sonuçlar Tablo 2' de ve Tablo 3'de verilmiştir. Öncelikle öğrencilerin elde ettikleri “Boş Zaman Tatmini”nin Yaşam Doyumuna 
olan etkisi incelenmiş. Ardından boş zaman tatmin ölçeğini meydana getiren boyutların yaşam doyumuna olan etki üzerinde bir inceleme yapılmıştır.

Tablo 2: Öğrencilerin boş zaman tahmininin yaşam doyumuna olan etki analizi

\begin{tabular}{|c|c|c|c|c|c|}
\hline \multirow{2}{*}{ Değisşkenler } & \multicolumn{2}{|c|}{$\begin{array}{c}\text { Standardize } \\
\text { Edilmemiş Katsayılar }\end{array}$} & \multirow{2}{*}{$\begin{array}{c}\begin{array}{c}\text { Standardize } \\
\text { Katsayılar }\end{array} \\
\beta \\
\end{array}$} & \multirow{2}{*}{$\mathbf{t}$} & \multirow[b]{2}{*}{$\mathbf{p}$} \\
\hline & B & $\begin{array}{l}\text { Standart } \\
\text { Hata }\end{array}$ & & & \\
\hline Sabit & 1,337 & 0,291 & & 4,598 & 0,000 \\
\hline Boş Zaman Tatmini &, 474 & 0,083 & 0,299 & 5,722 & 0,000 \\
\hline \multicolumn{6}{|c|}{ Bağımlı Değișken: Yaşam Doyumu } \\
\hline$R=0,299$ & \multicolumn{2}{|c|}{$\mathrm{R}^{2}=0,090$} & $\Delta \mathrm{R}^{2}=0,087$ & \multirow{2}{*}{\multicolumn{2}{|c|}{ urbin-Watson $=1,744$}} \\
\hline \multicolumn{4}{|c|}{$\mathrm{F}_{(2,1003)}=32,741 ; \mathrm{p}<0,000$} & & \\
\hline
\end{tabular}

Tablo 2'de verilen bilgiler, öğrencilerin boş zaman tatmininin yaşam doyumuna olan etkisi belirlemek üzere yapılan doğrusal regresyon analizi sonuçlarıdır. Yapılan analiz neticesinde boş zaman tatmini elde etmenin öğrencilerin yaşam doyumlarına (p:0,00<0,05) anlamlı şekilde etki ettiği belirlenmiştir. Boş zaman tatmini ile yaşam doyumu arasında pozitif yönlü bir ilişki oldu söylenebilir $(\mathrm{R}=0,299)$. Belirlilik kat sayıs1 ( $\mathrm{R} 2=0,090)$ olarak hesaplanmış, bu durum yaşam doyumu düzeyindeki değişkenliğin boş zamandan elde edilen tatmini \%9 olarak açıklanmaktadır. Bu durumda H1. Hipotezi: "ögrenciler boş zaman tatmininin yaşam doyumuna etkisi vardır" kabul edilmiştir.

Tablo 3'de öğrencilerin boş zaman tatminini meydana getiren 6 boyutun; eğitim, fizyolojik, estetik, rahatlama, sosyal ve psikolojik tatmin düzeylerinin, yaşam doyumuna olan etkisini belirlemek üzere yapılan doğrusal çoklu regresyon analiz sonuçlarına yer verilmiştir.

Tablo 3: Öğrencilerin boş zaman tatmini alt boyutlarının yaşam doyumu arasındaki çoklu regresyon analizi

\begin{tabular}{|c|c|c|c|c|c|}
\hline \multirow{2}{*}{\begin{tabular}{|l} 
Boyut \\
Değişkenleri
\end{tabular}} & \multicolumn{2}{|c|}{$\begin{array}{c}\text { Standardize Edilmemiş } \\
\text { Katsayılar }\end{array}$} & \multirow{2}{*}{$\begin{array}{c}\begin{array}{c}\text { Standardize } \\
\text { Katsayılar }\end{array} \\
\beta\end{array}$} & \multirow{2}{*}{$\mathbf{t}$} & \multirow{2}{*}{$\mathbf{P}$} \\
\hline & B & $\begin{array}{l}\text { Standart } \\
\text { Hata }\end{array}$ & & & \\
\hline Sabit & 1,258 & ,297 & & 4,323 & ,000 \\
\hline Ĕgitim &, 160 & ,081 & 0,207 & 1,960 & 051 \\
\hline Fizyolojik & ,129 & ,045 & 0,116 & 2,883 & ,004 \\
\hline Estetik &, 044 & ,049 & 0,268 &,- 902 & ,368 \\
\hline Rahatlama & 034 &, 044 & 0,058 &,- 785 & ,433 \\
\hline Sosyal & 056 & 076 & 0,281 & 740 & 460 \\
\hline Psikolojik & ,230 &, 080 & 0,195 & 2,860 & ,005 \\
\hline \multicolumn{6}{|c|}{ Bağımlı Değișken: Yaşam Doyumu } \\
\hline $\mathrm{R}=0,347$ & $\mathrm{R}^{2}=0,120$ & & $\Delta \mathrm{R}^{2}=0,104$ & \multirow{2}{*}{\multicolumn{2}{|c|}{ Durbin-Watson $=1,80^{7}$}} \\
\hline \multicolumn{4}{|c|}{$\mathrm{F}_{(2,1003)}=7,480 ; \mathrm{p}<0,000$} & & \\
\hline
\end{tabular}

* $\mathrm{p}<0,05$ gruplar arasında etki anlamlıdır,

Yapılan analiz neticesinde boș zaman tatmini elde etmede fizyolojik (p:0,04<0,05) ve psikolojik (p:0,05<0,05) yollardan elde edilen tatminin, yaşam doyumuna anlamlı bir şekilde etki ettiği belirlenmiştir. Boş zaman tatminini meydana getiren eğitim ( $\mathrm{p}: 0,051>0,05)$, estetik (p:0,368>0,05), rahatlama (p:0,433>0,05) ve sosyal (p:0,460>0,05) alanlardan elde edilen tatminin, yaşam doyumuna anlamlı bir etkisinin olmadığı belirlenmiştir. Boş zaman tatminini sağlayan alt boyutlar ile yaşam doyumu arasında genel olarak pozitif yönlü bir ilişki $(\mathrm{R}=0,347)$ olduğundan söz edilebilir. Belirlilik kat sayıs1 $(\mathrm{R} 2=0,120)$ olarak hesaplanmış, bu durum yaşam doyumu düzeyindeki değişkenliğin boş zamandan elde edilen tatmini \%12 olarak açıklanmaktadır. Sonuç olarak Tablo 3’ten elde edilen sonuçlara göre $\mathrm{H} 3$ hipotezi "boş zaman tatmini fizyolojik tatmin boyutunun yaşam doyumuna etkisi vardır" ve H7 hipotezi "Boş zaman tatmini psikolojik tatmin boyutunun yaşam doyumuna etkisi vardır" kabul edilmiştir. Diğer taraftan H4, H5 ve H6 hipotezleri kabul edilmemiştir. 
Tablo 4'de öğrencilerin boş zaman tatmini ve yaşam doyumları ile cinsiyet, yaş, eğitim düzeyi, uyku süresi, rekreatif mekân tercihi ve faaliyet katılım biçimleri arasındaki ilişkiye dair korelasyon analizi sonuçları verilmiştir.

Tablo 4'e göre öğrencilerin yaş düzeyleri ile boş zaman tatmini eğitim boyutu arasında pozitif yönlü anlamlı bir ilişki bulunmaktadır (r:0,098/p:0,036). Eğitim düzeyi ile eğitimden elde edilen tatmin arasında ters yönlü anlamlı bir ilişki olduğu belirlenmiştir (r:-154/p:0,002). Boş zamanlarda tercih edilen mekânlar bakımından fizyolojik ve rahatlama tatmini arasında ise anlamlı bir ilişki olduğu belirlenmiştir (r-0,114/p:0,019). Boş zamanlarda aktivitenin aktif ve pasif yapılmasına göre estetik ve sosyal tatmin arasında ters yönlü anlamlı bir ilişkinin var olduğu söylenebilir (r:-0,128/p:0,010). Eğitim, fizyolojik, sosyal, psikolojik tatmin ile öğrencilerin yaşam doyumları arasında pozitif yönlü anlamlı bir ilişki olduğu gözlenmektedir.

Tablo 4: Boş Zaman tatmini ve Alt boyutlarının yaşam doyumu arasındaki iliş̧i analizi

\begin{tabular}{|c|c|c|c|c|c|c|c|c|c|}
\hline & & 声 & $\begin{array}{l}:=1 \\
0 \\
0 \\
0 \\
0\end{array}$ & 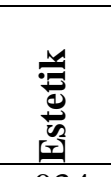 & 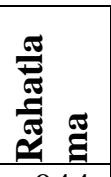 & $\begin{array}{l}\bar{\pi} \\
\overline{0} \\
0 \\
0 \\
0\end{array}$ & $\begin{array}{l}:=1 \\
0 \\
0 \\
\frac{1}{0} \\
e^{2}\end{array}$ & 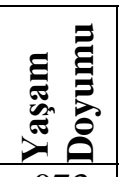 & 施 \\
\hline \multirow{2}{*}{ Cinsiyet } & $\mathrm{r}$ & ,043 & ,086 &,- 034 &,- 044 & \begin{tabular}{|c|}
,- 027 \\
\end{tabular} & \begin{tabular}{|c|}
,- 024 \\
\end{tabular} &, 073 &, 007 \\
\hline & p (sig.) & ,215 & 057 & ,266 & ,213 & ,309 & ,328 & ,090 & ,449 \\
\hline \multirow{2}{*}{ Yaş } & $\mathrm{r}$ & ,098* & 025 & 021 & ,007 &,- 041 &, 087 &,- 079 & 052 \\
\hline & p (sig.) &, 036 & ,326 & ,353 &, 452 & 225 & ,057 &, 075 &, 173 \\
\hline \multirow[t]{2}{*}{ Ĕ̆itim Düzeyi } & $\mathrm{r}$ & $\overline{-}^{-}, 154^{* *}$ &,- 005 &,- 008 &,- 034 & ,017 &,- 060 &,- 050 &,- 064 \\
\hline & $p$ (sig.) &, 002 & 462 & ,441 & ,266 &, 377 &, 137 &, 182 &, 121 \\
\hline \multirow{2}{*}{ Uyku } & $\mathrm{r}$ &,- 055 &,- 040 & 020 &,- 029 & 018 & ,008 & ,002 &,- 022 \\
\hline & p (sig.) &, 158 & ,234 & ,357 & ,298 & ,368 & ,443 & ,483 & ,344 \\
\hline \multirow{2}{*}{ Mekân } & $\mathrm{r}$ &,- 017 &,$- 114^{*}$ &, 027 & $173^{* *}$ &,- 031 & ,067 &,- 012 & ,014 \\
\hline & $p$ (sig.) & ,380 & ,019 & ,309 &, 001 & 286 & , 109 &, 410 & ,400 \\
\hline \multirow{2}{*}{ Aktivite } & $\mathrm{r}$ &,- 069 &,- 073 & ${ }^{-}, 128^{* * *}$ &,- 086 &,$- 111^{*}$ &,- 077 &,- 046 &,$- 135^{* *}$ \\
\hline & p (sig.) &, 103 & ,090 &, 010 & ,059 & ,021 & ,080 & ,203 & ,007 \\
\hline \multirow{2}{*}{ Yaşam Doyumu } & $\mathrm{r}$ &, $240^{* *}$ &, $235^{* *}$ &, 080 &, 085 &, $203^{* *}$ &, $275^{* *}$ & &, $299^{* *}$ \\
\hline & p (sig.) &, 000 &, 000 &, 071 &, 061 &, 000 &, 000 & &, 000 \\
\hline \multirow{2}{*}{ Boş Zaman Tatmini } & $\mathrm{r}$ &, $681^{* *}$ &, $566^{* *}$ &, $575^{* *}$ &, $582^{* *}$ &, $723^{* *}$ &, $781^{* *}$ & $299^{* *}$ & \\
\hline & $\mathrm{p}$ (sig.) &, 000 & 000 &, 000 &, 000 & ,000 & ,000 &, 000 & \\
\hline
\end{tabular}

$\mathrm{p}<0,01$ : ilişki düzeyi $\% 99$ oranında anlamlı

Öğrencilerin boş zaman elde etmesinde boş zamanı oluşturan alt boyutlar arasında pozitif yönlü anlam bir ilişkinin var dolduğundan söz edilebilir. Tablo 4'de görülen en temel sonuç boş zaman tatmini ile yaşam doyum arasında anlamlı bir ilişkinin var olduğu görülmektedir.

Tablo 5'de 2018-2019 eğitim öğretim yılı içerisinde aktif olarak öğrenci olanların boş zaman tatmini ve alt boyutları ile yaşam doyum algılarının cinsiyet faktörü bakımından gruplar arasındaki fark analizi; Mann Whitney U testi sonuçları ile boyutların aritmetik ortalama değerlerine yer verilmiştir. 
Tablo 5: Öğrencilerin Boş zaman Tatmini ve Alt Boyutları ile Yaşam doyumunun cinsiyete göre fark analizi

\begin{tabular}{|c|c|c|c|c|c|c|c|}
\hline BOYUT VE DEĞİŞKEN & Cinsiyet & $\mathbf{n}$ & $\begin{array}{l}\text { Sira } \\
\text { Ort. }\end{array}$ & $\overline{\mathbf{X}}$ & \begin{tabular}{|c|}
$\begin{array}{c}\text { Shapiro- } \\
\text { Wilk }\end{array}$ \\
\end{tabular} & $\mathbf{U}$ & $\mathbf{p}$ \\
\hline \multirow{2}{*}{ EĞİTiM } & Erkek & 165 & 162,23 & 3,45 & \multirow{2}{*}{0,000} & \multirow{2}{*}{$-1,076$} & \multirow{2}{*}{0,282} \\
\hline & Kadın & 170 & 173,60 & 3,51 & & & \\
\hline \multirow{2}{*}{ FİZYOLOJİK } & Erkek & 165 & 160,93 & 3,10 & \multirow{2}{*}{0,000} & \multirow{2}{*}{$-1,318$} & \multirow{2}{*}{0,187} \\
\hline & Kadın & 170 & 174,86 & 3,29 & & & \\
\hline \multirow{2}{*}{ ESTETÍK } & Erkek & 165 & 169,85 & 3,45 & \multirow{2}{*}{0,000} & \multirow{2}{*}{,- 345} & \multirow{2}{*}{0,730} \\
\hline & Kadın & 170 & 166,21 & 3,38 & & & \\
\hline \multirow{2}{*}{ RAHATLAMA } & Erkek & 165 & 168,33 & 3,81 & \multirow{2}{*}{0,000} & \multirow{2}{*}{,- 062} & \multirow{2}{*}{0,951} \\
\hline & Kadın & 170 & 167,68 & 3,70 & & & \\
\hline \multirow{2}{*}{ SOSYAL } & Erkek & 165 & 167,84 & 3,47 & \multirow{2}{*}{0,000} & \multirow{2}{*}{,- 029} & \multirow{2}{*}{0,977} \\
\hline & Kadın & 170 & 168,15 & 3,43 & & & \\
\hline \multirow{2}{*}{ PSİKOLOJİK } & Erkek & 165 & 166,90 & 3,54 & \multirow{2}{*}{0,000} & \multirow{2}{*}{,- 206} & \multirow{2}{*}{0,837} \\
\hline & Kadın & 170 & 169,07 & 3,50 & & & \\
\hline \multirow{2}{*}{ YAŞAM DOYUMU } & Erkek & 165 & 160,95 & 2,91 & \multirow{2}{*}{0,000} & \multirow{2}{*}{$-1,316$} & \multirow{2}{*}{0,188} \\
\hline & Kadın & 170 & 174,84 & 3,04 & & & \\
\hline \multirow{2}{*}{ BOŞ ZAMAN TATMINİ } & Erkek & 165 & 164,96 & 3,46 & \multirow{2}{*}{0,000} & \multirow{2}{*}{,- 565} & \multirow{2}{*}{0,572} \\
\hline & Kadın & 170 & 170,95 & 3,46 & & & \\
\hline
\end{tabular}

* $\mathrm{p}<0,05$ gruplar arasında fark vardır

Verilen yanıtlara göre Boş zaman tatmini sahip olmada cinsiyetler arasındaki karşılaştırmada anlamlı bir farklılık (p:0,572>0,050) gözlenmemiştir. Boş zaman tatmini elde etmede cinsiyet bakımından aritmetik ortalamanın eşit olduğu gözlenmiştir $(\overline{\mathrm{X}}: 3,46)$. Boş zaman tatmini meydana getiren altı alt boyut incelendiğinde kadınların eğitim $(\overline{\mathrm{X}}: 3,45)$ ve fizyolojik $(\overline{\mathrm{X}}: 3,29)$ alanlarda elde ettikleri tatminin erkeklere göre karşılaş̧ıııldığında boş zaman tatmini daha fazla olduğu gözlenmiştir. Erkekler, estetik $(\overline{\mathrm{X}}: 3,46)$, rahatlama $(\overline{\mathrm{X}}: 3,81),(\overline{\mathrm{X}}: 3,45)$, sosyal $(\overline{\mathrm{X}}: 3,47)$ ve psikolojik $(\overline{\mathrm{X}}: 3,54)$ tatmin boyutlarında elde ettikleri tatmin kadınlara oranla daha fazla olduğu söylenebilir. Sonuç olarak boş zaman tatmini elde etmede eğitim ve fizyolojik tatmin kadınlarda daha fazla iken, erkeklerde rahatlama, psikolojik ve sosyal faaliyetlerden elde edilen tatmin kadınlara göre daha fazla olduğu söylenebilir. Yine yaşam doyumu elde etmede katılımcıların cinsiyetler arasında anlamlı bir farklılı̆ga (p:0,188>0,050) rastlanmamıştır. Yaşam doyum ölçeğine verilen yanıtlarda kadınların $(\overline{\mathrm{X}}: 3,04)$ daha fazla yaşam doyumuna sahip olduğu gözlenmektedir.

Tablo 6'da öğrencilerin Boş zaman Tatmini ve alt boyutları ile yaşam doyum algılarının eğitim düzeyi grupları arasındaki farklılı̆̆ belirlemek üzere Mann Whitney U testi sonuçları ile eğitim düzeyleri bakımından boş zaman tatmini ve yaşam doyumuna ilişkin aritmetik ortalama sonuçları verilmiştir.

Verilen yanıtlara göre Boş zaman tatmini ve alt boyutlarında, öğrencilerin eğitim düzeyleri arasında yapılan karşılaştırmada anlamlı bir farklılık (p:0,185>0,050) gözlenmemiştir. Ön lisans okuyanların, eğitim $(\overline{\mathrm{X}}: 3,88)$, fizyolojik $(\overline{\mathrm{X}}: 3,46)$, estetik $(\overline{\mathrm{X}}: 3,45)$, rahatlama $(\overline{\mathrm{X}}: 3,91)$ ve psikolojik $(\overline{\mathrm{X}}: 3,70)$ tatminlerinin, lisans eğitim alanlara göre daha fazla olduğu belirlenmiştir. Boş zaman tatminine genel olarak bakıldığında Ön lisans okuyanların $(\overline{\mathrm{X}}: 3,60)$ lisans okuyanlara $(\overline{\mathrm{X}}: 3,45)$ göre daha fazla boş zaman tatmini elde ettikleri söylenebilir. Yaşam doyumu bakımından yapılan karşılaştırmada ön lisans ve lisan okuyanlar arasında anlamlı bir farklılığa (p:0,536>0,050) rastlanmamıştır. Aritmetik ortalamaları bakımından, Ön lisans okuyanların $(\overline{\mathrm{X}}: 3,15)$ yaşam doyumları lisans okuyanlara $(\overline{\mathrm{X}}: 2,96)$ göre daha fazla olduğu gözlenmiştir. 
Tablo 6: Öğrencilerin Boş zaman Tatmini ve Alt Boyutları ile Yaşam doyumunun eğitime göre fark analizi

\begin{tabular}{|c|c|c|c|c|c|c|c|c|}
\hline $\begin{array}{l}\text { BOYUT VE } \\
\text { DEĞISSTEN }\end{array}$ & $\begin{array}{l}\text { Ĕgitim } \\
\text { Durumu }\end{array}$ & n & $\begin{array}{l}\text { Sira } \\
\text { Ort. } \\
\end{array}$ & $\overline{\mathbf{X}}$ & \begin{tabular}{|c|}
$\begin{array}{c}\text { Shapiro- } \\
\text { Wilk }\end{array}$ \\
\end{tabular} & $\mathbf{U}$ & $\mathbf{p}$ & FARK \\
\hline \multirow{2}{*}{ EĞíTíM } & Ön lisans & 21 & 224,98 & 3,88 & \multirow{2}{*}{0,000} & \multirow{2}{*}{2100,5} & \multirow{2}{*}{, 005} & \multirow{2}{*}{$*$} \\
\hline & Lisans & 314 & 164,19 & 3,46 & & & & \\
\hline \multirow{2}{*}{ FİYYOLOJİK } & Ön lisans & 21 & 178,43 & 3,22 & \multirow{2}{*}{0,000} & \multirow{2}{*}{3078,0} & \multirow{2}{*}{,610 } & \multirow{2}{*}{ - } \\
\hline & Lisans & 314 & 167,30 & 3,19 & & & & \\
\hline \multirow{2}{*}{ ESTETİK } & Ön lisans & 21 & 169,69 & 3,45 & \multirow{2}{*}{0,000} & \multirow{2}{*}{3261,5} & \multirow{2}{*}{,934 } & \multirow{2}{*}{ - } \\
\hline & Lisans & 314 & 167,89 & 3,41 & & & & \\
\hline \multirow{2}{*}{ RAHATLAMA } & Ön lisans & 21 & 185,83 & 3,91 & \multirow{2}{*}{0,000} & \multirow{2}{*}{2922,5} & \multirow{2}{*}{,382 } & \multirow[t]{2}{*}{ - } \\
\hline & Lisans & 314 & 166,81 & 3,74 & & & & \\
\hline \multirow{2}{*}{ SOSYAL } & Ön lisans & 21 & 161,07 & 3,40 & \multirow{2}{*}{0,000} & \multirow{2}{*}{3151,5} & \multirow{2}{*}{, 735} & \multirow{2}{*}{-} \\
\hline & Lisans & 314 & 168,46 & 3,45 & & & & \\
\hline \multirow{2}{*}{ PSİKOLOJİK } & Ön lisans & 21 & 190,50 & 3,70 & \multirow{2}{*}{0,000} & \multirow{2}{*}{2824,5} & \multirow{2}{*}{,271 } & \multirow{2}{*}{ - } \\
\hline & Lisans & 314 & 166,50 & 3,51 & & & & \\
\hline \multirow{2}{*}{ YAŞAM DOYUMU } & Ön lisans & 21 & 180,64 & 3,15 & \multirow{2}{*}{0,000} & \multirow{2}{*}{3031,5} & \multirow{2}{*}{, 536} & \multirow[b]{2}{*}{ - } \\
\hline & Lisans & 314 & 167,15 & 2,96 & & & & \\
\hline \multirow{2}{*}{$\begin{array}{l}\text { BOŞ ZAMAM } \\
\text { TATMINI }\end{array}$} & Ön lisans & 21 & 195,10 & 3,60 & 0000 & 27280 & 185 & _ \\
\hline & Lisans & 314 & 166,19 & 3,45 & 0,000 & $2 / 28,0$ & & - \\
\hline
\end{tabular}

* $\mathrm{p}<0,05$ gruplar arasında fark vardır

Tablo 7'de öğrencilerin yaş aralıkları bakımından boş zaman tatmini ve alt boyutları ile yaşam doyumu algılarının gruplar arasındaki farkı Kruskal Wallis testi sonuçları ile yaş aralıkları bakımından boş zaman tatminini ve yaşam doyumlarının aritmetik ortalama sonuçları verilmiştir.

Verilen yanıtlara göre Boş zaman tatmini ve alt boyutlarında, yaşları bakımından yapılan karşılaştırmada gruplar arasında anlamlı bir farklılık (p:0,143>0,050) gözlenmemiştir. 31-60 yaş aralığında olan öğrencilerin boş zaman tatmini eğitim ( $\overline{\mathrm{X}}: 4,50)$, fizyolojik $(\overline{\mathrm{X}}: 4,08)$, estetik $(\overline{\mathrm{X}}: 3,75)$, rahatlama $(\overline{\mathrm{X}}: 4,62)$, sosyal $(\overline{\mathrm{X}}: 4,25)$ ve psikolojik $(\overline{\mathrm{X}}: 4,80)$ tatmini aritmetik ortalamalarının, diğer yaş gruplarına göre daha fazla olduğu belirlenmiştir.

Boş zaman tatminine genel olarak bakıldığında ise yine 31-60 yaş aralığında olanların $(\overline{\mathrm{X}}: 4,52)$ diğer yaş gruplarına göre daha fazla tatmin elde ettikleri söylenebilir.

Yaşam doyumu elde etmede yaşları bakımından yapılan karşılaştırmada ise yine gruplar arasında anlamlı bir farklılığa (p:0,445>0,050) rastlanmamıştır. Aritmetik ortalamaları bakımından, 18-22 yaş aralığında olanların $(\overline{\mathrm{X}}: 3,01)$ yaşam doyum ortalamalarının, diğer yaş gruplarına göre daha fazla olduğu gözlenmiştir. 
Tablo 7: Boş zaman Tatmini ve Alt Boyutları ile Yaşam doyumunun yaş aralıklarına göre fark analizi

\begin{tabular}{|c|c|c|c|c|c|c|c|}
\hline BOYUT VE DEĞIŞKENLER & Yaş & $\mathbf{n}$ & Sira Ort. & $\overline{\mathbf{X}}$ & $\begin{array}{c}\text { Shapiro- } \\
\text { Wilk }\end{array}$ & $\mathbf{x}^{2}$ & $\mathbf{p}$ \\
\hline \multirow{4}{*}{ EĞİTíM } & $18-22$ & 246 & 166,02 & 3,47 & \multirow{4}{*}{0,000} & \multirow{4}{*}{6,135} & \multirow{4}{*}{, 105 } \\
\hline & $23-25$ & 77 & 165,53 & 3,47 & & & \\
\hline & $26-30$ & 10 & 207,15 & 3,86 & & & \\
\hline & $31-60$ & 2 & 310,50 & 4,50 & & & \\
\hline \multirow{4}{*}{ FİZYOLOJí } & $18-22$ & 246 & 168,38 & 3,18 & \multirow{4}{*}{0,000} & \multirow{4}{*}{2,809} & \multirow{4}{*}{,422 } \\
\hline & $23-25$ & 77 & 165,56 & 3,24 & & & \\
\hline & $26-30$ & 10 & 155,55 & 3,00 & & & \\
\hline & $31-60$ & 2 & 278,00 & 4,08 & & & \\
\hline \multirow{4}{*}{ ESTETIK } & $18-22$ & 246 & 168,05 & 3,42 & \multirow{4}{*}{0,000} & \multirow{4}{*}{5,030} & \multirow{4}{*}{, 170} \\
\hline & $23-25$ & 77 & 162,45 & 3,34 & & & \\
\hline & $26-30$ & 10 & 180,25 & 3,50 & & & \\
\hline & $31-60$ & 2 & 314,50 & 4,75 & & & \\
\hline \multirow{4}{*}{ RAHATLAMA } & 18-22 & 246 & 167,36 & 3,76 & \multirow{4}{*}{0,000} & \multirow{4}{*}{2,414} & \multirow{4}{*}{,491 } \\
\hline & $23-25$ & 77 & 165,90 & 3,68 & & & \\
\hline & $26-30$ & 10 & 179,45 & 3,85 & & & \\
\hline & $31-60$ & 2 & 269,75 & 4,62 & & & \\
\hline \multirow{4}{*}{ SOSYAL } & $18-22$ & 246 & 169,73 & 3,48 & \multirow{4}{*}{0,000} & \multirow{4}{*}{4,149} & \multirow{4}{*}{, 246} \\
\hline & $23-25$ & 77 & 163,42 & 3,38 & & & \\
\hline & $26-30$ & 10 & 137,50 & 3,18 & & & \\
\hline & $31-60$ & 2 & 284,50 & 4,25 & & & \\
\hline \multirow{4}{*}{ PSİKOLOJÍK } & $18-22$ & 246 & 166,07 & 3,50 & \multirow{4}{*}{0,000} & \multirow{4}{*}{6,522} & \multirow{4}{*}{, 089} \\
\hline & $23-25$ & 77 & 166,42 & 3,51 & & & \\
\hline & $26-30$ & 10 & 195,20 & 3,75 & & & \\
\hline & $31-60$ & 2 & 330,00 & 4,80 & & & \\
\hline \multirow{4}{*}{ YAŞAM DOYUMU } & $18-22$ & 246 & 171,46 & 3,01 & \multirow{4}{*}{0,000} & \multirow{4}{*}{2,672} & \multirow{4}{*}{,445 } \\
\hline & $23-25$ & 77 & 163,36 & 2,75 & & & \\
\hline & $26-30$ & 10 & 127,10 & 2,56 & & & \\
\hline & $31-60$ & 2 & 125,50 & 2,60 & & & \\
\hline \multirow{4}{*}{ BOŞ ZAMAN TATMINİ } & $18-22$ & 246 & 166,67 & 3,46 & & & \\
\hline & $23-25$ & 77 & 166,55 & 3,43 & 0000 & 5424 & 143 \\
\hline & $26-30$ & 10 & 180,60 & 3,00 & 0,000 & $5,4 \angle 4$ & , \\
\hline & $31-60$ & 2 & 324,00 & 4,52 & & & \\
\hline
\end{tabular}

$\mathrm{p}<0,05$ gruplar arasında fark vardır

Tablo 8'de öğrencilerin günlük ortalama uyku süreleri bakımından boş zaman tatmini ve alt boyutları ile yaşam doyumu algılarının gruplar arasındaki farkı Kruskal Wallis testi sonuçları ile uyku süreleri bakımından boş zaman tatminini ve yaşam doyumlarının aritmetik ortalama sonuçları verilmiştir.

Verilen yanıtlara göre boş zaman tatmini ve alt boyutlarında, öğrencilerin görüşlerinde uyku süreleri arasında yapılan karşılaştırmada anlamlı bir farklılık (p:0,752>0,050) gözlenmemiştir. 1-6 saat uyuyanlar eğitim $(\overline{\mathrm{X}}: 3,50)$ ve rahatlama $(\overline{\mathrm{X}}: 3,77)$ boyutlarında daha fazla tatmin oldukları gözlenirken, 7-9 saat aralığında uyuyan ögrencileri ise fizyolojik $(\overline{\mathrm{X}}: 3,25)$, estetik $(\overline{\mathrm{X}}: 3,50)$ ve psikolojik $(\overline{\mathrm{X}}: 3,54)$ tatmin boyutlarında aritmetik ortalamaları daha yüksektir. 10 ila 12 saat aralığında uyku süresine sahip olanların ise sadece sosyal tatmin düzeyinin en yüksek olduğu belirlenmiştir.

Boş zaman tatminine genel olarak bakıldığında 7-9 saat aralığında uyuyanların $(\overline{\mathrm{X}}: 3,48)$ diğer gruplara göre daha fazla boş zaman tatmini elde ettikleri söylenebilir. Yaşam doyumu elde etmede uyku süreleri bakımından yapılan karşılaştırmada, katılımcıların görüşleri arasında anlamlı bir farklılığa (p:0,550>0,050) rastlanmamıştır.

Aritmetik ortalamaları bakımından, yine 7-9 saat aralığında uykuya sahip olanların $(\overline{\mathrm{X}}: 3,03)$ yaşam doyumları diğer gruplara göre daha fazla olduğu gözlenmiştir. 
Tablo 8: Boş zaman Tatmini ve Alt Boyutları ile Yaşam doyumunun uyuma sürelerine göre fark analizi

\begin{tabular}{|c|c|c|c|c|c|c|c|}
\hline BOYUT VE DEĞISSKENLER & Uyku Süresi & $\mathbf{n}$ & Sira Ort. & $\overline{\mathbf{x}}$ & $\begin{array}{l}\text { Shapiro- } \\
\text { Wilk }\end{array}$ & $\mathrm{x}^{2}$ & $\mathbf{p}$ \\
\hline \multirow{4}{*}{ EĞİTİM } & $1-6$ & 144 & 170,68 & 3,50 & \multirow{4}{*}{0,000} & \multirow{4}{*}{2,369} & \multirow{4}{*}{0,500} \\
\hline & $7-9$ & 164 & 169,59 & 3,49 & & & \\
\hline & $10-12$ & 26 & 146,81 & 3,33 & & & \\
\hline & 12 ve üzeri & 1 & 73,00 & - & & & \\
\hline \multirow{4}{*}{ FİYYOLOJİ } & $1-6$ & 144 & 169,53 & 3,20 & \multirow{4}{*}{0,000} & \multirow{4}{*}{4,348} & \multirow{4}{*}{0,226} \\
\hline & $7-9$ & 164 & 172,39 & 3,25 & & & \\
\hline & $10-12$ & 26 & 130,67 & 2,83 & & & \\
\hline & 12 ve üzeri & 1 & 198,00 & - & & & \\
\hline \multirow{4}{*}{ ESTETÍK } & $1-6$ & 144 & 163,29 & 3,35 & \multirow{4}{*}{0,000} & \multirow{4}{*}{2,135} & \multirow{4}{*}{0,545} \\
\hline & $7-9$ & 164 & 174,15 & 3,50 & & & \\
\hline & $10-12$ & 26 & 158,81 & 3,27 & & & \\
\hline & 12 ve üzeri & 1 & 77,00 & - & & & \\
\hline \multirow{4}{*}{ RAHATLAMA } & $1-6$ & 144 & 163,63 & 3,77 & \multirow{4}{*}{0,000} & \multirow{4}{*}{1,981} & \multirow{4}{*}{0,57} \\
\hline & $7-9$ & 164 & 173,59 & 3,76 & & & \\
\hline & $10-12$ & 26 & 160,58 & 3,63 & & & \\
\hline & 12 ve üzeri & 1 & 72,50 & - & & & \\
\hline \multirow{4}{*}{ SOSYAL } & $1-6$ & 144 & 171,62 & 3,45 & \multirow{4}{*}{0,000} & \multirow{4}{*}{1,486} & \multirow{4}{*}{0,686} \\
\hline & $7-9$ & 164 & 162,26 & 3,43 & & & \\
\hline & $10-12$ & 26 & 183,88 & 3,58 & & & \\
\hline & 12 ve üzeri & 1 & 175,00 & - & & & \\
\hline \multirow{4}{*}{ PSİKOLOJÍK } & $1-6$ & 144 & 167,46 & 3,50 & \multirow{4}{*}{0,000} & \multirow{4}{*}{1,427} & \multirow{4}{*}{0,699} \\
\hline & $7-9$ & 164 & 170,08 & 3,54 & & & \\
\hline & $10-12$ & 26 & 162,02 & 3,51 & & & \\
\hline & 12 ve üzeri & 1 & 60,00 & - & & & \\
\hline \multirow{4}{*}{ YAŞAM DOYUMU } & $1-6$ & 144 & 165,28 & 2,94 & \multirow{4}{*}{0,000} & \multirow{4}{*}{2,111} & \multirow{4}{*}{0,550} \\
\hline & $7-9$ & 164 & 172,54 & 3,03 & & & \\
\hline & $10-12$ & 26 & 151,00 & 2,77 & & & \\
\hline & 12 ve üzeri & 1 & 256,00 & - & & & \\
\hline \multirow{4}{*}{ BOŞ ZAMAN TATMINİ } & $1-6$ & 144 & 169,21 & 3,46 & & & \\
\hline & $7-9$ & 164 & 169,27 & 3,48 & $0 \cap 00$ & 1205 & 0752 \\
\hline & $10-12$ & 26 & 156,65 & 3,37 & 0,000 & 1,200 & $0, / 32$ \\
\hline & 12 ve üzeri & 1 & 81,50 & - & & & \\
\hline
\end{tabular}

Tablo 9'da Öğrencilerin boş zaman tatmini ve alt boyutları ile yaşam doyum algılarının boş zaman mekân tercihi faktörü bakımından dört grup arasındaki farklılığı belirlemek üzere Kruskal Wallis testi sonuçları ile boş zaman mekân tercihinin boş zaman tatminini ve yaşam doyumlarının aritmetik ortalama sonuçları verilmiştir.

Verilen yanıtlara göre Boş zaman tatmini ve alt boyutlarında, öğrencilerin görüşlerinde boş zaman mekân tercihi bakımından yapılan karşılaştırmada gruplar arasında anlamlı bir farklılık (p:0,787>0,050) gözlenmemiş̧ir. Boş zaman tatmininde mekân tercihi olarak Açık Alan (Kır) ifadesi tercih edenlerin eğitim $(\overline{\mathrm{X}}: 3,52)$ ve fizyolojik $(\overline{\mathrm{X}}: 3,33)$ tatminde aritmetik ortalaması yüksek olduğu belirlenmiştir. Aritmetik ortalama olarak Estetik, Rahatlama, Psikolojik tatmin boyutlarında en yüksek ortalamaya sahip olanları ise Açık Alan (Kent) tercihinde bulunanlar olduğu gözlenmiştir.

Boş zaman tatminine genel olarak bakıldığında ise tüm mekânları tercih edenlerin $(\overline{\mathrm{X}}: 3,57)$ aritmetik olarak en yüksek tatmin sağladıkları söylenebilir. Yaşam doyumu elde etmede mekân tercihleri bakımından gruplar arasında anlamlı bir farlılık (p:0,018<0,050) gözlenmiştir.

Bu anlamda Açık Alan (Kent) ifadesinin Kapalı Alan ifadesiyle farklılaştı̆̆ı, Kapalı Alan ifadesinin Açık Alan (Kent) ile farklılaştığı ve Hepsi ifadesine verilen yanıtların sadece Açık Alan (Kır) ile farklılaştığ 1 , ancak yaşam doyumu boyutunda Açık alan (Kır) ifadesinin diğer gruplarla farklılaşmadığ söylenebilir.

Aritmetik ortalamaları bakımından, boş zamanlarında tüm mekânları tercih edenlerin $(\overline{\mathrm{X}}: 3,01)$ yaşam doyumu elde etmede, diğer mekân tercih gruplarına göre daha fazla doyum sağladığı söylenebilir. 
Tablo 9: Öğrencilerin Boş zaman Tatmini ve Alt Boyutları ile Yaşam doyumunun mekân tercihine göre fark analizi

\begin{tabular}{|c|c|c|c|c|c|c|c|c|}
\hline $\begin{array}{l}\text { BOYUT VE } \\
\text { DEĞISSENLER }\end{array}$ & Mekân Tercihi & $\mathbf{n}$ & $\begin{array}{l}\text { Sura } \\
\text { Ort. }\end{array}$ & $\overline{\mathbf{X}}$ & $\begin{array}{l}\text { Shapiro- } \\
\text { Wilk }\end{array}$ & $\mathbf{x}^{2}$ & $\mathbf{p}$ & FARK \\
\hline \multirow{4}{*}{ EĞíTíM } & Açık alan (KIR) & 124 & 173,40 & 3,52 & \multirow{4}{*}{0,000} & \multirow{4}{*}{3,123} & \multirow{4}{*}{0,373} & - \\
\hline & $\begin{array}{c}\text { Açık } \\
\text { alan(KENT) }\end{array}$ & 119 & 162,46 & 3,46 & & & & - \\
\hline & Kapalı Alan & 76 & 160,80 & 3,43 & & & & - \\
\hline & Hepsi & 16 & 201,53 & 3,64 & & & & - \\
\hline \multirow{4}{*}{ FİZYOLOJİ } & Açık alan (KIR) & 124 & 175,98 & 3,33 & \multirow{4}{*}{0,000} & \multirow{4}{*}{4,400} & \multirow{4}{*}{0,221} & - \\
\hline & $\begin{array}{c}\text { Açık } \\
\text { alan(KENT) }\end{array}$ & 119 & 173,15 & 3,20 & & & & - \\
\hline & Kapalı Alan & 76 & 152,78 & 3,01 & & & & - \\
\hline & Hepsi & 16 & 140,13 & 2,97 & & & & - \\
\hline \multirow{4}{*}{ ESTETIKK } & Açık alan (KIR) & 124 & 157,11 & 3,35 & \multirow{4}{*}{0,000} & \multirow{4}{*}{3,409} & \multirow{4}{*}{0,333} & - \\
\hline & $\begin{array}{c}\text { Açık } \\
\text { alan(KENT) }\end{array}$ & 119 & 178,18 & 3,50 & & & & - \\
\hline & Kapalı Alan & 76 & 166,32 & 3,36 & & & & - \\
\hline & Hepsi & 16 & 184,72 & 3,57 & & & & - \\
\hline \multirow{4}{*}{ RAHATLAMA } & Açık alan (KIR) & 124 & 149,45 & 3,49 & \multirow{4}{*}{0,000} & \multirow{4}{*}{7,654} & \multirow{4}{*}{0,054} & - \\
\hline & $\begin{array}{c}\text { Aç1k } \\
\text { alan(KENT) }\end{array}$ & 119 & 175,52 & 3,81 & & & & - \\
\hline & Kapalı Alan & 76 & 184,14 & 4,03 & & & & - \\
\hline & Hepsi & 16 & 179,22 & 4,00 & & & & - \\
\hline \multirow{4}{*}{ SOSYAL } & Açık alan (KIR) & 124 & 168,03 & 3,47 & \multirow{4}{*}{0,000} & \multirow{4}{*}{3,339} & \multirow{4}{*}{0,342} & - \\
\hline & $\begin{array}{c}\text { Açık } \\
\text { alan(KENT) }\end{array}$ & 119 & 173,70 & 3,48 & & & & - \\
\hline & Kapalı Alan & 76 & 153,45 & 3,34 & & & & - \\
\hline & Hepsi & 16 & 194,53 & 3,59 & & & & - \\
\hline \multirow{4}{*}{ PSİKOLOJİK } & Açık alan (KIR) & 124 & 162,16 & 3,45 & \multirow{4}{*}{0,000} & \multirow{4}{*}{0,967} & \multirow{4}{*}{0,809} & - \\
\hline & $\begin{array}{c}\text { Açık } \\
\text { alan(KENT) }\end{array}$ & 119 & 171,03 & 3,56 & & & & - \\
\hline & Kapalı Alan & 76 & 169,67 & 3,54 & & & & - \\
\hline & Hepsi & 16 & 182,81 & 3,70 & & & & - \\
\hline \multirow{4}{*}{ YAŞAM DOYUMU } & $\begin{array}{l}\text { a-Açık alan } \\
\text { (KIR) }\end{array}$ & 124 & 164,24 & 2,91 & \multirow{4}{*}{0,000} & \multirow{4}{*}{10,096} & \multirow{4}{*}{0,018} & - \\
\hline & $\begin{array}{c}\text { b-Açık } \\
\text { alan(KENT) }\end{array}$ & 119 & 185,03 & 3,16 & & & & $\mathrm{c}$ \\
\hline & c-Kapali Alan & 76 & 142,55 & 2,72 & & & & $\mathrm{~b}$ \\
\hline & d-Hepsi & 16 & 191,38 & 3,23 & & & & $\mathrm{a}$ \\
\hline & Açık alan (KIR) & 124 & 164,69 & 3,45 & & & & - \\
\hline BOŞ ZAMAN & $\begin{array}{c}\text { Açık } \\
\text { alan(KENT) }\end{array}$ & 119 & 171,97 & 3,48 & 0,000 & 1,057 & 0,787 & - \\
\hline & Kapalı Alan & 76 & 163,43 & 3,42 & & & & - \\
\hline & Hepsi & 16 & 185,84 & 3,57 & & & & - \\
\hline
\end{tabular}

$\mathrm{p}<0,05$ gruplar arasında fark vardır

Tablo 10'da boş zaman tatmini ve alt boyutları ile Yaşam doyum algılarının aktivite türü faktörü bakımından gruplar arasındaki farklılığa ilişkin Kruskal Wallis testi sonuçları ile aktivite türüne göre boş zaman tatminini ve yaşam doyumlarının aritmetik ortalama sonuçları verilmiştir.

Verilen yanıtlara göre Boş zaman tatmini ve alt boyutlarında, öğrencilerin görüşlerinde aktivite türü bakımından yapılan karşılaştırmada, estetik, rahatlama, psikolojik tatmin boyutların anlamlı bir farklılık gözlenmiştir. Genel olarak boş zaman tatmininde, öğrencilerin aktivite türü tercihleri bakımından 
cevapları arasında da farklılık (p:0,003<0,050) bulunmaktadır. Aktivite türü bakımından aktif ve pasif etkinlik tercih edenler kendi aralarında farklılaşmaktadır.

Boş zaman tatmin ölçeği ve alt boyutlarında yer alan ifadelerin aritmetik ortalamalarına bakıldığında aktif nitelikli etkinlikleri tercih edenlerin, estetik $(\overline{\mathrm{X}}: 3,50)$ ve sosyal $(\overline{\mathrm{X}}: 3,77)$ tatmin boyutlarında daha fazla tatmin oldukları gözlenirken, fizyolojik $(\overline{\mathrm{X}}: 3,96)$, rahatlama $(\overline{\mathrm{X}}: 3,92)$ ve psikolojik $(\overline{\mathrm{X}}: 3,66)$ boyutlarında her iki etkinlik tipini tercih edenlerin daha fazla tatmin oldukları aritmetik olarak gözlenmiştir.

Sonuç olarak Aktif katılımlı boş zaman faaliyetleri tercih edenlerin daha fazla tatmin oldukları belirlenmiştir. Yaşam doyumu elde etmede eğitim programı bakımından yapılan karşılaştırmada katılımcıların görüşleri arasında anlamlı bir farklılığa (p:0,848>0,050) rastlanmamıştır.

Tablo 10: Öğrencilerin Boş zaman Tatmini ve Alt Boyutları ile Yaşam doyumunun aktivite türüne göre fark analizi

\begin{tabular}{|c|c|c|c|c|c|c|c|c|}
\hline $\begin{array}{l}\text { BOYUT VE } \\
\text { DEĞİSKENLER }\end{array}$ & $\begin{array}{c}\text { Aktivite } \\
\text { Türü }\end{array}$ & $\mathbf{n}$ & $\begin{array}{l}\text { Sira } \\
\text { Ort. }\end{array}$ & $\overline{\mathbf{X}}$ & $\begin{array}{l}\text { Shapiro- } \\
\text { Wilk }\end{array}$ & $\mathbf{x}^{2}$ & $\mathbf{p}$ & FARK \\
\hline \multirow{3}{*}{ EĞİTíM } & Aktif & 186 & 175,84 & 3,54 & \multirow{3}{*}{0,000} & \multirow{3}{*}{4,086} & \multirow{3}{*}{0,130} & - \\
\hline & Pasif & 133 & 155,04 & 3,40 & & & & - \\
\hline & Hepsi & 16 & 184,66 & 3,54 & & & & - \\
\hline \multirow{3}{*}{ FİYYOLOJI } & a-Aktif & 186 & 180,88 & 3,26 & \multirow{3}{*}{0,000} & \multirow{3}{*}{7,477} & \multirow{3}{*}{0,024} & - \\
\hline & b-Pasif & 133 & 152,57 & 3,13 & & & & - \\
\hline & c-Hepsi & 16 & 146,56 & 3,96 & & & & - \\
\hline \multirow{3}{*}{ ESTETIK } & a-Aktif & 186 & 181,83 & 3,56 & \multirow{3}{*}{0,000} & \multirow{3}{*}{9,895} & \multirow{3}{*}{0,007} & $\mathrm{~b}$ \\
\hline & b-Pasif & 133 & 147,61 & 3,20 & & & & $\mathrm{a}$ \\
\hline & c-Hepsi & 16 & 176,75 & 3,45 & & & & - \\
\hline \multirow{3}{*}{ RAHATLAMA } & a-Aktif & 186 & 177,13 & 3,88 & \multirow{3}{*}{0,000} & \multirow{3}{*}{6,401} & \multirow{3}{*}{0,041} & $\mathrm{~b}$ \\
\hline & b-Pasif & 133 & 152,14 & 3,56 & & & & $\mathrm{a}$ \\
\hline & c-Hepsi & 16 & 193,69 & 3,92 & & & & - \\
\hline \multirow{3}{*}{ SOSYAL } & Aktif & 186 & 178,15 & 3,53 & \multirow{3}{*}{0,000} & \multirow{3}{*}{4,611} & \multirow{3}{*}{0,100} & - \\
\hline & Pasif & 133 & 155,41 & 3,35 & & & & - \\
\hline & Hepsi & 16 & 154,59 & 3,35 & & & & - \\
\hline \multirow{3}{*}{ PSİKOLOJİK } & a-Aktif & 186 & 178,41 & 3,59 & \multirow{3}{*}{0,000} & \multirow{3}{*}{6,711} & \multirow{3}{*}{0,035} & $\mathrm{~b}$ \\
\hline & b-Pasif & 133 & 151,25 & 3,40 & & & & $\mathrm{a}$ \\
\hline & c-Hepsi & 16 & 186,22 & 3,66 & & & & - \\
\hline \multirow{3}{*}{ YAŞAM DOYUMU } & Aktif & 186 & 171,63 & 3,00 & \multirow{3}{*}{0,000} & \multirow{3}{*}{0,848} & \multirow{3}{*}{0,654} & - \\
\hline & Pasif & 133 & 164,85 & 2,96 & & & & - \\
\hline & Hepsi & 16 & 151,91 & 2,78 & & & & - \\
\hline \multirow{3}{*}{$\begin{array}{l}\text { BOŞ ZAMAN } \\
\text { TATMİNI }\end{array}$} & a-Aktif & 186 & 183,34 & 3,54 & \multirow{3}{*}{0,000} & \multirow{3}{*}{11,638} & \multirow{3}{*}{0,003} & $\mathrm{~b}$ \\
\hline & b-Pasif & 133 & 145,91 & 3,34 & & & & $\mathrm{a}$ \\
\hline & c-Hepsi & 16 & 173,28 & 3,47 & & & & - \\
\hline
\end{tabular}

* $\mathrm{p}<0,05$ gruplar arasinda fark vardır

Aritmetik ortalamaları bakımından, aktif katılımlı boş zaman faaliyetlerini tercih edenlerin olanların yaşam doyumları $(\overline{\mathrm{X}}: 3,00)$ diğer gruplara göre daha fazla olduğu gözlenmiştir. Yapılan tüm testler ve analizler neticesinde elde edilen verilere ilişkin sonuç ve öneri izleyen paragrafta verilmiştir.

\section{SONUÇ}

Genel olarak bu çalışma, boş zaman tatmininin, yaşam doyumuna olan etkisine ve aralarındaki ilişkiye odaklanırken, bunun yanında öğrencilerin demografik ve kişisel farklılıklarına ilişkin sorular kapsamında boş zaman ve yaşam doyum tatminleri arasında gözlemlenen farklılıkları belirlenmesi hedefleyen bir çalışma olmuştur. Boş zaman tatmini ve yaşam doyumu arasındaki etkiyi ve ilişkiyi öngören iki ayrı teori çerçevesinde hipotezler geliştirilmiş ve test edilmiştir. Bu kapsamda yapılan testler kapsamında elde edilen sonuçlara göre araştırma bulguları izleyen paragrafta verilmiştir.

Öğrencilerin boş zaman tatminleri ile yaşam doyumları arasındaki etkiyi ölçmek üzere yapılan basit regresyon analizi sonucunda boş zaman tatmininin yaşam doyumu üzerinde etkili olduğu H1 (KABUL) belirlenmiştir. Bu kapsamda elde edilen sonuç Cha (2018)'nın yaşıı bireyler üzerine yapmış olduğu 
çalışmasında, boş zaman etkinliklerine katılımın yaşadıkları yalnızlaşmaya yardımcı olabileceği ve öz saygılarını ve kendini gerçekleştirmelerini sağlayarak daha fazla yaşam memnuniyeti elde edileceği sonucuna uyum göstermektedir. Adams ve arkadaşlarının (2011) yaptığı A Critical Review Of The Literature On Social And Leisure Activity And Wellbeing in Later Life adlı çalışmada, boş zaman aktivitelerine katılım sıklığının, yaşlı yetişkinler için daha yüksek bir yaşam kalite güvencesi sağladığını ve daha mutlu yaşamalarını sağladığı sonucu, elde edilen sonuç ile benzerlik göstermektedir.

Öğrencilerin boş zaman tatminini oluşturan alt boyutların, yaşam doyumlarına etkisi üzerine yapılan çoklu regresyon analizine göre sadece fizyolojik ve psikolojik tatminin, yaşam doyumuna $\mathrm{H} 2$ (KABUL), H7(KABUL) etkisi olduğu gözlenmiştir. Bu durumda Yi ve Park (2009)'ın yaşlı yetişkinler üzerine yaptığı çalışmada yaşam kalitesini artırmak veya iyileştirmek için, fiziksel ve psikolojik sağlıklarında iyileştirmeler getirebilecek boş zaman etkinliklerine katılma firsatlarının arttırılması gerektiği önerisi doğrultuda bir sonuca ulaşılmıştır. Bu kapsamda öğrenciler, boş zaman tatmini ve yaşam doyumu elde etmede, eğitim, estetik (öz bakım), rahatlama, dinlenme ve sosyal katılım gibi çeşitli aktiviteler için zamanlarını nasıl harcadıkları konusunda kendilerini geliştirmeli ve iyi bir denge sağlamalılardır. Schmiedeberg, ve Schröder, (2017). Leisure Activities And Life Satisfaction: An Analysis With German Panel Data, adlı çalışmada boş zamanlarda yapılan fiziksel aktivitelerin, tatile çıkmanın ve sosyal aktivitelerde bulunmanın yaşam doyumunu olum yönde etkilediğini, gereksiz internet ve televizyon kullanımının yaşam doyumunu olumsuz etkilediği sonucu, çalışma sonucumuzu destekler niteliktedir.

Araştırma kapsamında yapılan korelasyon analizi sonucunda yaşam doyumu ve boş zaman tatmini arasında pozitif yönlü anlamlı bir ilişki olduğu belirlenmiştir. Rodríguez, ve arkadaşlarının (2008). The Relationship Between Leisure And Life Satisfaction: Application Of Activity And Need Theory, adlı çalışmada Alman halkı üzerine yapmış oldukları araştırmada, boş zaman tatmini ile yaşam doyumu arasında anlamlı bir ilişki olduğu sonucu elde edilen korelasyon sonucu ile parelellik göstermektedir. Korelasyon analizinden elde edilen diğer sonuçlara göre; öğrencilerin cinsiyet faktörü bakımından boș zaman tatminleri ile yaşam doyumları arasında anlamlı bir ilişkinin bulunmadığı gözlenmiştir. Yaş faktörü bakımından sadece boş zaman tatmini sağlayan eğitim boyutu arasında pozitif yönlü anlamlı bir iliş̧i bulunmuştur. Boş zaman tatmini elde etmede mekâna bağlı olarak açık alan, kapalı alan ve hepsi yapılan değerlendirmede, tercih edilen mekân ile fizyolojik tatmin boyutu ile rahatlama tatmin boyutu anlamlı bir şekilde ilişki göstermiştir.

Öğrencilerin boş zaman tatminlerinin ve yaşam doyumlarının cinsiyet faktörü bakımından gruplar arasında anlamlı bir farklılığa rastlanmamıştır. Boş zaman tatmini alt boyutları bakımından da gruplar arasında yine anlamlı bir farklılık gözlenmemiştir. Elde edilen sonuç Ardahan ve Yerlisu Lapa (2010), Çelik (2011) ve Çakır (2017) tarafından yapılan çalışmalarla paralellik göstermektedir. Ancak Çakır (2017) çalışmasındaki boş zaman tatmini alt boyutları bakımından psikolojik tatmin ile rahatlama boyutları arasında cinsiyet grupları arasında anlamlı farklılık gözlenmiştir. Kılıç ve arkadaşlarının (2013) Rekreasyonel Tatmin ve Yaşam Doyumu Arasındaki İlişkinin İncelenmesi adlı çalışmada ise cinsiyet grupları arasında boş zaman tatmini bakımında anlamlı farkların olduğu hatta tüm alt boyutlarında anlamlı şekilde farklılaştığı belirtilmektedir. Ancak yaşam doyumu bakımından gruplar arasındaki farklılık incelemesinde benzer sonuç elde edilmiştir.

Araştırmada üniversitedeki tüm düzeyde eğitim alan öğrenciler hedef kitle alınsa da veri toplanan grup sadece lisans ve ön lisans öğrencileri olmuştur. Eğitim seviyesine göre yapılan karşılaştırmada ön lisans ile lisans okuyan öğrenciler arasında boş zaman tatmin düzeyleri arasında anlamlı bir farklılığa rastlanılmamıştır. Ancak boş zaman tatmin ölçeğinin eğitim boyutunda gruplar arasında eğitim tatmini bakımından anlamlı bir farklılık gözlenmiştir. Yaşam doyumu bakımından gruplar arasında anlamlı bir farkl11ık gözlenmemiştir.

Araştırmaya katılan öğrencilerin boş zaman tatmini ve yaşam doyumlarına ilişkin görüşleri arasında yaşları bakımından elde edilen analiz sonucuna göre gruplar arasında anlamlı bir farklılığa rastlanılmamıştır. Öğrencilerin uyku süresi sorusuna 1-6 saat, 7-9 saat, 10-12 ve 12 saat üzeri aralığında uyuduklarını belirtmişlerdir. Boş zaman tatmini ve yaşam doyumu bakımından öğrencilerin uyuma süreleri kendi aralarında anlamlı bir şekilde farklılaşmamaktadır.

Öğrencilere yöneltilen boş zamanlarınızı değerlendirmek üzere tercih ettiğiniz mekânlara Açık Alan (Kır), Açık Alan (Kent), Kapalı Alan ve Hepsi şeklinde yanıtlar vermişlerdir. Bu kapsamda öğrenciler boş zaman tatmini bakımından mekân tercihlerine göre yapılan karşılaştırmada gruplar arasında anlamlı bir ilişkiye rastlanmamıştır. Ancak yaşam doyumu ölçeğine verilen yanıtlar bakımından gruplar arasında 
anlamlı farklılık gözlenmiştir. İfadeler bazında Açık alan (Kır)'1 tercih edenler hiçbir mekân ile farklılaşmazken, Açık Alan(Kent)'i tercih edenler Kapalı alan ile farklılaşırken, Kapalı Alan'ı tercih edenler Açık Alan (Kent) ile farklılaşmış, Hepsi'ni tercih edenler ise sadece Açık Alan (Kır)'ı tercih edenlerle farklılaştı̆̆ gözlenmiştir.

Öğrencilere boş zamanlarını aktivitelerine katılım türüne göre değerlendirme sorusuna aktif, pasif ve hepsi şeklinde yanıt vermişlerdir. Bu kapsamda elde edilen bulgulara göre boş zaman tatmini bakımından verilen yanıtlara göre gruplar arasında anlamlı bir farklılığın olduğu belirlenmiștir. İfadeler bazında Hepsi yanıtı verenler diğer ifadelerle farklılık göstermezken, Aktif ve Pasif yanıtını verenler kendi içerisinde anlamlı farklılık göstermektedir. Aktivite türüne göre yaşam doyumu konusunda gruplar arasında anlamlı bir farklılığa rastlanmamıştır.

Araştırma kapsamında elde edilen sonuçlar neticesinde öğrencilerin boş zaman tatmini eğitim ve sosyal boyutundan aldıkları tatminin yaşam doyumunu çok fazla etkilemediği gözlenmiştir. $\mathrm{Bu}$ kapsamda kampüs içerisinde yapılacak olan sosyal ve eğitim tatminine yönelik çalışmalarla öğrencilerin yaşam doyum düzeyleri yükseltilebilir. Ayrıca bir sayfiye destinasyonu olan Alanya'da eğitim alan ögrencilerin elde ettikleri boş zaman tatmin ve yaşam doyum aritmetik ortalamalarının $\overline{\mathrm{X}}: 2,00-\overline{\mathrm{X}}: 3,80$ aralığında olması, ortalama düzeyde bir boş zaman tatminine ve yaşam doyumuna sahip olduğunu göstermektedir. Bu kapsamda bu değerleri arttırmak üzere öğrencilerle yüz yüze mülakatlar yapılarak daha fazla nasıl katkı sağlanabileceği araştırılabilir. Bu yönüyle bu çalışma ileride yapılacak çalışmalara yol gösterici olabilir. 


\section{KAYNAKÇA}

ACH (1980). Physical Education and Recreation/Royal Australian Institute of Parks and Recreation, Australian Council for Health, Recreation Working Paper, Adelaide: Achper Publications,

Appleton, S. and Song, L. (2008). Life Satisfaction in Urban China: Components And Determinants. World Development, (36) $11,2325-2340$

Argan, M., Yüncü, D., Coşkun, O., Sevil, T., Özel, Ç.H., Yüncü, H.R. ve Şimşek, K.Y. (2013). Rekreasyon Yönetimi, Eskişehir: Anadolu Üniversitesi Yayınları.

Ardahan, F. ve Lapa, T.Y. (2010). Üniversite Öğrencilerinin Serbest Zaman Tatmin Düzeylerinin Cinsiyete Ve Gelire Göre İncelenmesi. Spor Bilimleri Dergisi, 21(4), 129-136.

Arıkan, R. (2004). Araştırma Teknikleri Ve Rapor Hazırlama. Ankara: Asil Yayın.

Brightbill C.K. (1960) The Challenge of Leisure. Englewood Cliffs, NJ, PrenticeHall,

Cha, Y.J. (2018). Correlation Between Leisure Activity Time and Life Satisfaction: Based on KOSTAT Time Use Survey Data. Occupational Therapy International.

Çakır, V.O. (2017). Üniversite Öğrencilerin Serbest Zaman Doyum Düzeyleri İle Serbest Zaman Yönetimleri Arasındaki İlişki. Gaziantep Üniversitesi Spor Bilimleri Dergisi, 2(3), 17-27.

Çelik, G. (2011). Kamu Kuruluşlarında Çalışan Engelli Bireylerin Serbest Zaman Engellerinin Ve Tatmin Düzeylerinin İncelenmesi (Antalya Merkez Örneği). Yayımlanmamış yüksek lisans tezi. Akdeniz Üniversitesi Sosyal Bilimler Enstitüsü, Antalya.

Dağlı, A. ve Baysal, N. (2016). Yaşam Doyumu Ölçeğinin Türkçe 'ye Uyarlanması: Geçerlik ve Güvenirlik Çalışması. Elektronik Sosyal Bilimler Dergisi, 15(59), 1250-1262

Freire, T. and Teixeira, A. (2018). The Influence of Leisure Attitudes and Leisure Satisfaction on Adolescents Positive Functioning: The Role of Emotion Regulation. Frontiers in psychology, 9.

Gajewska, P. and Piskrzyńska, K. (2017). Leisure Time Management. In Forum Scientiae Oeconomia, 5(1), 57-69.

Gökçe, H. (2008). Serbest Zaman Doyumunun Yaşam Doyumu Ve Sosyo-Demografik Değişkenlerle İlişkisinin İncelenmesi, Yayımlanmamış Yüksek lisans Tezi, Pamukkale Üniversitesi Sağlık Bilimleri Enstitüsü, Denizli

Hamida, N.H., Ahmada, A.R. and Awang M.M. (2016). The Effect Of Leısure Time Activities On Life Quality Of Youth in Malaysia, International Conference On Education And Regional Development, Indonesia 728-731

Hilooğlu, S. and Cenkseven-Önder, F. (2010). The Role Of Social Skills And Life Satisfaction in Predicting Bullying Among Middle School Students, Elementary Education Online, 9(3), 1159-1173.

Hou, JJ, Tu, HH, and Yang, MF. (2007). Agreeableness And Leisure Satisfaction in The Context of Online Games, Social Behavior and Personality, 35(10), 1379-1384.

Adams, K.B. Leibbrandt, S. and Moon, H. (2011). A Critical Review of The Literature On Social And Leisure Activity And Wellbeing in Later Life, Ageing and Society, 31(4), 683-712,

Karl, Ü., Polat, E., Yılmaz, B. ve Koçak, S. (2008). Serbest Zaman Tatmin Ölçeği'nin (Sztö-Uzun Versiyon) Geçerlilik Ve Güvenilirlik Çalışması. Spor Bilimleri Dergisi, 19(2), 80-91.

Kement, Ü. ve Güçer, E. (2015). Kamping Yapan Bireylerin Çevre Dostu Rekreasyon Davranışlarına Ekolojik Tutum Ve Rekreasyonel Motivasyon Değişkenlerinin Etkisinin İncelenmesi. Journal of Recreation \& Tourism Research, 2(3), 16-27.

Kılıç, S. (2013). Örnekleme yöntemleri. Journal of Mood Disorders, 3(1), 44-6.

Kılıç, S.K., Atasoy, K.L., Gürbüz, B. ve Öncü, E. (2013). Rekreasyonel Tatmin Ve Yaşam Doyumu Arasındaki İlişkinin İncelenmesi. İstanbul Üniversitesi Spor Bilimleri Dergisi, 6(3), 56-70.

Lapa, T.Y. (2013). Life Satisfaction, Leisure Satisfaction And Perceived Freedom Of Park Recreation Participants. Procedia-Social And Behavioral Sciences, 93, 1985-1993.

Lippman, L., Guzman, L. and Moore, K.A. (2012). Measuring Flourishing Among Youth: Findings from the Flourishing Children Positive Indicators Project. Webinar.

Lloyd, C, King, R, Lampe, J, and McDougall, S. (2001). The Leisure Satisfaction of People With Psychiatric Disabilities. Psychiatric Rehabilitation Journal, 25(2),107-113.

Lloyd, K.M. and Auld, C.J. (2002). The Role Of Leisure İn Determining Quality of Life: Issues Of Context And Measurement. Social Indicators Research, 57, 43-71.

$\mathrm{Lu}, \mathrm{L}$ and Hu, C.H. (2005). Personality, Leisure Experiences And Happiness. Journal of Happiness Studies, 6, 325-342.

Lysyk, M, Brown, GT, Rodrigues, E, Mc-Nally, J and Loo, K. (2002). Translation of the leisure satisfaction scale into French: A validation study. Occupational Therapy International, 9(1), 76-89.

Madiha, M. and Akhouri, D. (2018), Self Efficacy And Life Satisfaction Among Young Adults, International Journal of Applied Science Engineering and Management, 4(2), 19-29

Misra, R, and McKean, M. (2000). College Students' Academic Stress And İts Relation To Their Anxiety, Time Management and Leisure Satifaction, American Journal of Health Studies, 16(1), 41-51.

Muzindutsi, P. F. and Masango, Z. (2015). Determinants Of Leisure Satisfaction Among Undergraduate Students At A South African University. International Journal of Business and Management Studies, 7(1,2), 33-47

Ngai, VT. (2005). Leisure Satisfaction And Quality Of Life in Macao, China. Leisure Studies, 24(2),195-207.

Nunnally, J.C. and Bernstein, I.H. (1994). Validity. Psychometric theory, 3, 99-132. 
Özdamar, K. (2001). Temel Örnekleme Yöntemleri (Çev. Alptekin Esin, Celal Aydın and Diğerleri). Literatür Yayınları, İstanbul.

Pearson, Q.M. (2008). Role Overload, Job Satisfaction, Leisure Satisfaction, And Psychological Health Among Employed Women, Journal of Counseling and Development, 86,(2), 57-63.

Pieper J. (1965) Leisure: The Basis of Culture. London, Fontana

Prasoon, R. and Chaturvedi K.R. (2016). Life Satisfaction: A literature Review The Researcher- International Journal of Management Humanities and Social Sciences, 1(2) 25-32

Rodríguez, A., Látková, P. and Sun, Y.Y. (2008). The Relationship Between Leisure And Life Satisfaction: Application of Activity And Need Theory. Social Indicators Research, 86(1), 163.

Schmiedeberg, C. and Schröder, J. (2017). Leisure Activities And Life Satisfaction: An Analysis With German Panel Data, Applied Research in Quality of Life, 12(1), 137-151.

Siegenthaller, K.L. and Dell, I. (2000). Leisure Attitude, Leisure Satisfaction, And Perceived Freedom in Leisure Within Family Dyads. Leisure Sciences, 22, 281-295.

Tepeköylü Öztürk Ö. (2019). Leisure Satisfaction of Sports Science Students, International Education Studies, 12(4), 4248.

Trottier, A.N, Brown, GT, Hobson, SJG and Miller, W. (2002). Reliability And Validity Of Leisure Satisfaction Scale (LSS Short Form) And The Adolescent Leisure Interest Profile (ALIP). Occupational Therapy International, 9(2), 131-144.

Trujillo, J.L. (2007). Leisure Meanings, Experiences and Benefits: A Cross-cultural Analysis of Young Adults, Doctoral dissertation, University of Florida, USA

Veal, A.J. (1992). Definitions of Leisure And Recreation. Australian Journal of Leisure and Recreation, 2(4), 44-48.

Veenhoven, R. (2015). The Overall Satisfaction With Life: Subjective approaches (1). In Global Handbook of Quality of Life. Dordrecht: Springer,

Wang, E.S.T., Chen, L.S.L., Lin, J.Y.C. and Wang, M.C.H. (2008). The Relationship Between Leisure Satisfaction And Life Satisfaction Of Adolescents Concerning Online Games. Adolescence, Academic Research Library, 43(169), 177-184

Yaşartürk, F., Akyüz, H. ve Karataş, İ. (2017). Rekreatif Etkinliklere Katılan Üniversite Öğrencilerinin Serbest Zamanda Sıkılma Algısı İle Yaşam Doyum Düzeyleri Arasındaki İlişkinin İncelenmesi. Uluslararası Kültürel ve Sosyal Araştırmalar Dergisi (UKSAD), 3(Special Issue 2), 239-252.

Yaşartürk, F., Akyüz, H., Karatas, İ. and Türkmen, M. (2018). The Relationship between Free Time Satisfaction and Stress Levels of Elite-Level Student-Wrestlers. Education Sciences, 8(3), 133-144

Yazıcıoğlu, Y. ve Erdoğan, S. (2004). SPSS Uygulamalı Bilimsel Araştırma Yöntemleri. Ankara: Detay Yayıncılık.

Yi, Y.S. and Park, K.R. (2009). A Study Of Leisure Constraints, Leisure Activities Participation And Life Satisfaction of The Elderly, Korean Journal of Human Ecology, 18(1), 1-12

Yürcü, G. (2017). Rekreatif Faaliyet Katılım Alanlarına Göre Bireylerin Öfke İfade Tarzlarının Negatif-Pozitif Duygulanım Ve Yaşam Doyumları Üzerindeki Etkisi. Visionary E-Journal/Vizyoner Dergisi, 8(18). 26-40 